\title{
PENGARUH BERBAGAI INSEKTISIDA ORGANIK TERHADAP SERANGAN HAMA KUTU BERAS (Sitophylus oryzae L.) PADA BERBAGAI VARIETAS BERAS.
}

\author{
Oleh Sri Rahmi, Dwi Fitriani, Fiana Pondesta \\ (Alumni FP UMB dan **dosen FP UMB)
}

\begin{abstract}
ABSTRAK
Penelitian ini bertujuan untuk mengetahui ketahanan beberapa jenis beras terhadap tingkat serangan hama kutu beras (S. oryzae), pengaruh insektisida organik dalam mengendalikan hama kutu beras (S. oryzae), dan pengaruh interaksi beberapa insektisida organik dan jenis beras terhadap tingkat serangan hama kutu beras (S. oryzae)varietas Penelitian dilakukan di Laboratorium Karantina tumbuhan kota Bengkulu pada bulan April sampai dengan bulan Juni 2020. Penelitian menggunakan rancangan acak lengkap faktorial dengan 2 (dua) faktor. Faktor Pertama Jenis beras (V) yang terdiri dari 4 taraf yaitu (V1) Varietas Mekongga, (V2) Varietas Ciherang, (V3) Varietas IR-64, (V4) Varietas Cigeulis. Faktor Kedua Insektisida Organik (I) yang terdiri dari 5 (Lima) taraf yaitu Tampa Pemberian Insektisida (I0), Insektisida Daun Sirsak (I1), Insektisida Daun Jeruk Nipis (I2), Insektisida daun Mengkudu (I3), Insektisida daun Serei (I4) dan masing masing perlakuan di ulang sebanya tiga kali sehingga di dapat 60 unit percobaan.

Adapun peubah yang diamati antara lain : serangga yang hidup, beras rusak, beras utuh dan Jumlah tepung yang terbentuk. Hasil analisis data secara statistik menunjukkan bahwa ketahanan beras beberapa varietas padi menunjukkan hasil yang berpengaruh nyata terhadap serangga yang hidup, beras rusak, beras utuh dan jumlah tepung yangterbentuk. Dapat disimpulkan bahwa Varietas IR-64 adalah varietas yang paling tahan terhadap serangan Hama Gudang (Sitophillus oryzae) dibandingkan dengan varietas lainnya, diketahui bahwa kandungan amilosa pada beras Varietas IR64 mencapai $27 \%$, ini jelas lebih tinggi dari varietas lainnya yang diamati yang rata-rata hanya 23\%. Pemberian insektisida organik terhadap beras tidak memberi pengaruh yang nyata sehingga terdapat hasil tidak bepengaruh nyata dengan adanya kombinasi perlakuan antara varietas beras dan pemberian insektisida organik, ini di karenakan insektisida organis yang di gunakan hanya bersifat menolah hama gudang bukan untuk mematikan. Disarankan perlunya penelitian lanjutan dengan menggunakan varietas padi lokal dan dengan insektisida organik lainnya.
\end{abstract}

Kata kunci : Ketahanan beras, Varietas, beras, Sitophillus oryzae, Insektisida Organik 


\begin{abstract}
This study aimed to determine the resistance of several types of rice to the level of attack by Rice Weevil (Sitophilus Oryzae L) pests, the effect of organic insecticides in controlling Rice Weevil (Sitophilus Oryzae L) pests, and the effect of the interaction of several organic insecticides and types of rice on the level of attack by Rice Weevil (Sitophilus Oryzae L) pests varieties. The study was conducted at the Plant Quarantine LaboratoryBengkulu city from April to June 2020. The study implemented a factorial completely randomized design with 2 (two) factors. First Factor Type of rice (V) which consisted of 4 levels, namely (V1) Mekongga variety, (V2) Ciherang variety, (V3) IR-64 variety, (V4) Cigeulis variety. The second factor was Organic Insecticide (I) which consisted of 5 (five) levels, namely without Giving Insecticide (I0), Soursop Leaf Insecticide (I1), Lime Leaf Insecticide (I2), Noni Leaf Insecticide (I3), Serei Leaf Insecticide (I4 ) and each treatment was repeated three times so that 60 experimental units were obtained.

The variables observed were: live insects, damaged rice, whole rice and the amount of flour formed. The results of statistical data analysis indicated that rice resistance of several rice varieties showed a significant effect on live insects, damaged rice, whole rice and the amount of flour formed. It can be concluded that IR-64 variety is the most resistant variety against the Rice Weevil (Sitophilus Oryzae L) pestsattack compared to other varieties. It is known that the amylose content in IR64 variety rice reaches $27 \%$, this is clearly higher than other varieties observed which is only $23 \%$ on average. The application of organic insecticides to rice did not have a significant effect so that the results had no significant effect with the combination of treatments between rice varieties and organic insecticides. This is because the organic insecticide used is only to repel warehouse pests, not to slay them.It is suggested that further research is needed using local rice varieties and other organic insecticides
\end{abstract}

Keywords: Rice resistance, variety, rice, Sitophillus oryzae, Organic Insecticide

BAB I PENDAHULUAN
Indonesia menempati peringkat ketiga sebagai negara yang memproduksi 
beras terbesar di dunia pada tahun 2014 sebanyak 70.600 .000 ton, sedangkan peringkat pertama ditempati oleh China dengan produksi sebanyak 208.100.000 ton, peringkat kedua ditempati oleh India dengan produksi sebanyak 155.500 .000 ton (FAOSTAT, 2014 ).

Sebelum didistribusikan kepada masyarakat oleh pemerintah stok beras di simpan terlebih dahulu di Bulog (Badan Urusan Logistik) hal ini di lakukan dalam upaya menstabilkan jumlah stok dan harga beras di pasaran namun karena proses penyimpanan yang cukup lama maka akan banyak terjadi masalah dalam proses penyimpanan tersebut seperti serangan dari kutu beras.

Banyak kehilangan komoditas berupa menurunnya mutu, bertambahnya kadar air, kotoran benda asing, kerusakan bentuk, warna, bau, rasa, dan kehilangan kualitas berupa penyusutan berat harus diperhatikan selama penyimpanan.

Menurut FAO, kehilangan hasil panen di negara-negara berkembang berkisar antara 10-13\%, diantaranya berkisar 5\% oleh serangan hama gudang seperti serangga, tikus, tungau, burung, dan jasad renik. Bulog memperkirakan susut bobot beras sekitar 25\%, terdiri dari $8 \%$ waktu panen, $5 \%$ waktu pengangkutan, $2 \%$ waktu pengeringan, $5 \%$ waktu penggilingan, dan $5 \%$ waktu penyimpanan (Ramsiks, 2010).

Banyak upaya serta penelitiaan yang dilakukan dalam upaya mengurangi susut bobot beras setelah pasca panen beras salah satunya penyusutan bobot beras ketika penyimpanan. Namun salah satu hal yang sering terlewatkan adalah pada proses penyimpanan yaitu kemungkinan terjadinya penurunan kualitas akibat serangan hama gudang. Hama gudang yang paling sering menyerang pada proses penyimpanan beras adalah Sitophilus oryzae L. Serangga ini memiliki periode perkembangan yang singkat dan mampu berkembang biak dengan sangat cepat.

S. oryzae yang berasal dari Ordo Coleoptera merupakan serangga perusak yang menimbulkan kerusakan secara fisik dan mikrobiologis (mutu dan rasa) beras selama pada tempat penyimpanan. Selama perkembangan dari telur sampai imago $S$. oryzae dapat menurunkan produksi sampai $20 \%$ dalam waktu 5 minggu. Faktor yang menentukan derajat kerusakan beras oleh $S$. Oryzae dalam masa penyimpanan antara lain oleh pengaruh populasi, varietas asal beras, serta lama penyimpanan beras (Hendrik, 2016).

$$
\text { Perlindungan terhadap }
$$
penyimpanan produk pertanian dari ancaman hama serangga biasanya bergantung pada insektisida buatan seperti contoh organoklor, organofosfat dan karbamat. Penggunaan insektisida sintetik yang tidak bijaksana akan merusak lingkungan dan kesehatan manusia. Hal ini terjadi karena tidak semua insektisida yang digunakan mampu menangani organisme penganggu tanaman (IPT) sasaran, selain itu juga dapat membunuh organisme yang mungkin masih berguna. Salah satu tujuan praktis sistem pengendalian hama terpadu adalah mengurangi penggunaan insektisida sintetik antara lain dengan mengintroduksikan Insektisida Organik yang mampu menandingi kemampuan insektisida sintetik tersebut (Hendrik 2016).

Penggunaan Insektisida Organik merupakan salah satu alternatif yang dapat digunakan untuk mengatasi kekurangan insektisida sintetis. Insektisida Organik diartikan sebagai insektisida yang bahannya berasal dari bahan tumbuhan, karena 
terbuat dari bahan alami maka mudah terurai di alam sehingga residunya mudah hilang, relatif aman bagi manusia, mudah diperoleh dan dapat diramu oleh petani.

Insektisida Organik ini dapat berfungsi sebagai penolak, penarik, antifertilitas (pemandul), pembunuh dan bentuk lainnya. Sifat toksik dari suatu zat tergantung dari lamanya pengaplikasian, jenis spesies, dan umur (Hendrik, 2016)

Berdasarkan latar belakang di atas maka perlu di lakukan penelitian tentang pengaruh berbagai insektisida organik terhadap serangan hama gudang kutu beras (Sitophylus oryzae L.) pada berbagai jenis beras.

\section{BAB II METODOLOGI PENELITIAN}

\subsection{Tempat dan Waktu Penelitian}

Penelitian ini telah dilaksanakan pada bulan April 2020 sampai dengan bulan Juni 2020 dan bertempat di laboratorium Karantina Tumbuhan, kota Bengkulu.

\subsection{Alat dan Bahan}

Alat yang digunakan dalam penelitian ini yaitu, toples kecil, kuas kecil, lup, alat tulis, kertas tempel, lakban, lilin, korek api, jarum pentul, timbangan, plastik, dan mikroskop stereo. Sedangkan bahan yang digunakan dalam penelitian ini adalah beras berbagai Varietas ( Mekongga, Ciherang, IR-64, Cigeulis ).

\subsection{Metodologi Penelitian}

Tabel 3. Analisis ragam untuk masing-masing faktor dan interaksinya terhadap semua peubah
Peubah Yang di Amati
F hitung

Faktorial merupakan rancangan yang dipakai dalam penelitian ini. Perlakuan disusun secara faktorial. Faktor pertama (V) Varietas beras empat faktor dan faktor kedua (I) Insektisida organik lima factor, Penelitian perlakuan diulang sebanyak tiga kali, sehingga terdapat 20 kombinasi dan di lakukan 3 (Tiga) kali penggulangan sehingga di dapat 60 toples penelitian Peletakkan toples dilakukan secara acak

(V) Varietas beras

(V1) Varietas Mekongga

(V2) Varietas Ciherang

(V3) Varietas IR-64

(V4) Varietas Ciguelis

Insektisida Organik

(I0) Tanpa Pemberian Insektisida

(I1) Insektisida Daun Sirsak

(I2) Insektisida Daun Jeruk Nipis

(I3) Insektisida Daun Mengkudu

(I4) Insektisida Daun Serai

\section{BAB III}

\section{HASIL DAN PEMBAHASAN}

\subsection{Hasil}

Hasil analisis keragaman untuk masing-masing faktor dan interaksinya terhadap semua peubah yang diamati dalam penelitian dapat dilihat pada tabel 2 dibawah ini. 


\begin{tabular}{lllr}
\hline & V & I & V . I \\
\hline Jumlah Serangga & $22.76 * *$ & $1.80 \mathrm{tn}$ & $0.86 \mathrm{tn}$ \\
Beras Yang Rusak & $23.85 * *$ & $1.77 \mathrm{tn}$ & $2.07 *$ \\
Beras Utuh & $28.86 * *$ & $1.64 \mathrm{tn}$ & $1.97 \mathrm{tn}$ \\
Tepung Yang Terbentuk & $84.85 * *$ & $0.48 \mathrm{tn}$ & $1.24 \mathrm{tn}$ \\
\hline
\end{tabular}

$\begin{array}{ccl}\text { Keterangan } & : & \\ \text { V } & : & \text { Varietas Beras } \\ \text { I } & : & \text { Insektisida Organik } \\ \text { V . I } & : & \text { Interaksi } \\ \text { tn } & : & \text { Tidak Berpengaruh Nyata } \\ * & : & \text { Berpengaruh Nyata } \\ * * & : & \text { Berpengaruh Sangat Nyata }\end{array}$

\subsection{Pembahasan}

Berdasarkan hasil analisis data secara statistik menunjukan bahwa ketahanan beberapa beras varietas padi (Iryza sativa) terhadap serangan hama gudang (Sitopilus oryzae) menunjukkan hasil berpengaruh sangat nyata, namum penambahan insektisida organik dan interaksi antara insektisida organik dan varietas beras tidak berpengaruh nyata, kecuali pada peubah beras rusak terdapat hasil berpengaruh nyata akibat adanya interaksi antara varietas beras dengan penambahan insektisida organiik.

Dari peubah yang diamati yaitu kumbang hidup, beras rusak, beras utuh dan jumlah tepung yang terbentuk.Varietas padi IR-64 menunjukkan hasil yang paling bagus terhadap peubah yang diamati dibandingkan varietas Ciherang, varietas Mekongga dan varietas Cigeluis.

Varietas padi IR-64 berdasarkan penelitian merupakan varietas padi yang paling tahan diantara varietas lainnya terhadap serangan hama gudang (Sitopilus oryzae) Apabila di lihat dari hasil pengamatan terhadap peubah yang di amati terlepas dari interaksi antara jenis beras dan insektisida organic yang di gunakan karena perlakuan pemberian insektisida organic tidak memberi pengaruh yang nyata.

Dalam setiap peubah yang di amati Varietas padi IR-64 memberikan hasil yang lebih baik di antara jenis beras lain di susul varietas cigeulis, mekongga, dan ciherang.

Varietas padi IR-64 menjadi varietas yang paling tahan terhadap serangan hama gudang kutu beras karena di duga mempunyai kandungan amilosa yang lebih tinggi dibanding varietas padi lainnya yang diamati. Dilihat pada deskripsi Varietas Padi IR-64 diketahui bahwa kandungan amilosa pada beras Varietas IR-64 mencapai $27 \%$, ini jelas lebih tinggi dari varietas lainnya yang diamati yang rata-rata hanya $23 \%$ (litbang pertanian, 2015). 


\section{DAFTAR PUSTAKA}

Damanik, M. Madjid, B [et al]. 2010. Kesuburan Tanah dan Pemupukan. Universitas Sumatera Utara Press. Medan. 214 Halaman

FAO.food and agriculture organization of the united nations Statistics. at FAO 2017 http://www.fao.org/statistics/en/diakses $\underline{31 \text { mei } 2017}$

Hendrik. 2016. Pengaruh pestisida nabati terhadap serangan hama gudang kutu beras (Sitophilus oryzae L) pada berbagai jenis beras. Lampung. 113 Halaman skripsi untuk tidak di publikasikan

Nita,O. 2013. Pemanfaatan Daun Jeruk Nipis (Citrus aurantifolia) dan batang

serai (andropogon nardus l) untuk insektisida alami pembasmi kutu beras (sitophilus oryzae). Universitas Muhammadiyah Surakarta. Surakarta. 15 Halaman

Nurulhuda, A. 2013. Resistensi Relatif Beras Pecah Kulit Dan Beras Sosoh Lima Varietas Padi Asal Banyumas Terhadap Serangan Sitophilus Oryzae. [Skripsi] Departemen Ilmu dan Teknologi Pangan Fakultas Teknologi Pertanian IPB. Bogor.
Norsalis. 2011. Padi Gogo Dan Padi Sawah.Universitas Sumatera Utara. Medan.13 halaman

Marbun, C.U. dan Y. Pangestiningsih. 1991. Ketahanan Beberapa Jenis Beras Simpan terhadap Hama Bubuk Beras, Sitophylus orizae (Coleoptera, Curculionidae) di Gudang. Fakultas Pertanian USU. Medan.

Pracaya. 1991. Hama Dan Penyakit Tumbuhan. Penebar Swadaya. Jakarta. 417 halaman.

Puslitbang Tanaman Pangan. 2006. Inovasi teknologi Padi. Badan Penelitian dan pengembangan Pertanian, Departemen Pertanian.

Purwono dan Heni $\quad$ P. 2007.Budidaya 8 Jenis Pangan unggul. Depok: Penebar

Rahayu, T. 2009. Budidaya Tanaman Padi Dengan Teknologi MIG-6 plus. Jakarta 13 halaman

Rahmawati,N. Uji Efektifitas Ekstrak Daun Sirsak (Annona Muricata L) Sebagai Pestisida Nabati Terhadap Pengendalian Hama Tanaman Sawi (Vrassica Juncea L). Universitas Muhammadiyah Surakarta.

Ramsiks. 2010. Pengaruh Penggunaan Berbagai Warna Cahaya dan Jenis Beras terhadap Daya Preferensi dan Mortalitas (Sitophylus oryzae Linn.) 
Departemen Ilmu Hama dan Penyakit Tumbuhan Fakultas Pertanian Universitas Sumatera Utara. Medan. 121 Halaman

Rukmana, R. dan S. Saputra. 1995. Hama Tanaman. Bumi Aksara. Jakarta. 206 halaman.

Tandiabang, J., A. Tenrirawe, dan Surtikanti. 2009. Pengelolaan Hama Pasca Panen Jagung. Balai Penelitian Tanaman Serealia. Jakarta.

Wagianto, 2008. Hama-hama Tanaman dalam Gudang. Jakarta: Bumi Aksara. 